\title{
EFFECTS OF THE ARTIFICIAL-AGING TEMPERATURE AND TIME ON THE MECHANICAL PROPERTIES AND SPRINGBACK BEHAVIOR OF AA6061
}

\author{
VPLIV TEMPERATURE IN ČASA UMETNEGA STARANJA NA \\ MEHANSKE LASTNOSTI IN VZMETNOST AA6061
}

\author{
Aytekin Polat ${ }^{1}$, Mustafa Avsar ${ }^{1}$, Fahrettin Ozturk ${ }^{2}$ \\ 1Department of Mechanical Engineering, Nigde University, Nigde, Turkey \\ 2Department of Mechanical Engineering, The Petroleum Institute, Abu Dhabi, United Arab Emirates \\ apolat@nigde.edu.tr
}

Prejem rokopisa - received: 2013-09-20; sprejem za objavo - accepted for publication: 2014-09-08

doi:10.17222/mit.2013.154

\begin{abstract}
In this study, the effects of the artificial-aging temperature and time on the mechanical properties and springback behavior of AA6061 are investigated. The results reveal that the yield strength, the tensile strength and the elongations decreased with the increasing artificial-aging temperature, but increased with the increasing artificial-aging time up to the peak age. The springback of the alloy increased significantly with the increasing artificial-aging time at the artificial-aging temperature ranging from 160 ${ }^{\circ} \mathrm{C}$ to $180{ }^{\circ} \mathrm{C}$ and decreased with the artificial-aging time at $200{ }^{\circ} \mathrm{C}$. The springback angle in the as-received condition is lower than in all the aged conditions.
\end{abstract}

Keywords: aluminum alloy, AA6061, artificial aging, mechanical properties, springback

V tej študiji so bili preiskovani vplivi temperature in časa umetnega staranja na mehanske lastnosti in vzmetnost AA6061. Rezultati so pokazali zmanjšanje meje tečenja, natezne trdnosti in raztezka pri naraščanju temperature umetnega staranja ter povečevanje teh vrednosti do maksimuma pri podaljšanju časa staranja. Vzmetnost zlitine občutno narašča z naraščanjem časa umetnega staranja v območju temperatur od $160{ }^{\circ} \mathrm{C}$ do $180^{\circ} \mathrm{C}$ in se zmanjša s časom umetnega staranja pri $200{ }^{\circ} \mathrm{C}$. Kot vzmetnosti v dobavljenem stanju je manjši kot pri vseh staranih razmerah.

Ključne besede: aluminijeva zlitina, AA6061, umetno staranje, mehanske lastnosti, vzmetnost

\section{INTRODUCTION}

The 6xxx-series aluminum alloys are widely used in many industries such as aerospace, automotive and food industry due to their high strength-to-mass ratio, good corrosion resistance, good mechanical properties or a combination of these properties. ${ }^{1}$ In these alloys, all the alloying elements and impurities contribute, to various degrees, to the strengthening of aluminum matrix through solution hardening and dispersion hardening. $\mathrm{Mg}$ and $\mathrm{Si}$ are the major solid-solution strengtheners. They increase the strength of an alloy by precipitation hardening (also called age hardening). ${ }^{2}$ Precipitation hardening is a heat-treatment process used to improve the mechanical properties of the age-hardenable alloys. The process produces fine particles of an impurity phase and these precipitates impede the movement of dislocations. Any obstacles that make dislocation movement difficult harden the materials. There has been a considerable industrial interest in these alloys because two thirds of all the extruded products are made of aluminum, and $90 \%$ of these are made of the 6xxx series alloys. The AA6061 alloy is one of the most widely used aluminum alloys from the $6 x x x$ series. ${ }^{3}$ It is an age-hardenable alloy, whose mechanical properties are mainly controlled with the hardening precipitates contained in the material.
When the material is subjected to a solution heat treatment followed by quenching and artificial aging, its mechanical properties reach their highest levels and become very good compared to the other aluminum alloys.

Since the AA6061 alloy is a precipitation-hardenable material, its hardness, strength, and work-hardening capability are determined by the level of the solutes in the solid-solution matrix and the amount, type, density, size and nature of the second-phase particles. ${ }^{4}$ The precipitation sequence for the $6 \mathrm{xxx}$ alloys, which is generally accepted in the literature ${ }^{5-7}$ is: $\operatorname{SSSS} \rightarrow$ atomic clusters (Si clusters and $\mathrm{Mg}$ clusters) $\rightarrow$ dissolution of $\mathrm{Mg}$ clusters $\rightarrow \mathrm{Mg}$, Si co-clusters $\rightarrow$ precipitates of an unknown structure (GP-I zones) $\rightarrow \beta$ ' ' (GP-II zones) $\rightarrow$ B' and $\beta^{\prime} \rightarrow \beta$ (stable $\mathrm{Mg}_{2} \mathrm{Si}$ ). Here SSSS represents the supersaturated solute solution and GP stands for Guinier-Prestone zones.

The most effective hardening phase for these types of materials is $\beta$ ". The formation of a stable $\beta$ phase $\left(\mathrm{Mg}_{2} \mathrm{Si}\right)$ is preceded by a chain of transformations involving various coherent and semi-coherent meta-stable phases. Specifically, the sequence is: the formation of independent clusters of the $\mathrm{Mg}$ and $\mathrm{Si}$ atoms from the supersaturated solute solution, the formation of co-clusters that contain both $\mathrm{Si}$ and $\mathrm{Mg},{ }^{4}$ the formation and 
growth of $\beta$ " needle-shaped precipitates, the transformation of the $\beta$ " precipitates into $\beta$ ' lath-shaped precipitates and $\beta$ ' rod-shaped precipitates, followed, after long annealing times, by the formation of an incoherent, stable $\beta$. The co-clusters form after the dissolution of the $\mathrm{Mg}$ clusters; these were also found in naturally aged alloys. Compared to the co-clusters, the GP-I zones are thermally more stable; they contain more solute atoms and are spherical, with typical sizes of $1-3 \mathrm{~nm} .{ }^{8}$ The pre$\beta$ " phases are coherent, while $\beta$ ' is semi-coherent (coherent with the Al matrix along the axis of the needle). The rod-shaped phases $\mathrm{B}^{\prime}$ and $\beta$ ' form consecutively. These phases are typical for over-aged structures. The needleshaped $\beta "\left(\mathrm{Mg}_{5} \mathrm{Si}_{6}\right)$ precipitates are associated with peak-aged states. ${ }^{8}$ The precipitate particles and solute atoms generally formed in these alloys are obstacles to the dislocation accumulation and arrangement. They affect the development of a dislocation substructure with a special distribution of dislocation accumulation, the flexibility of dislocation movements, the initial trapping behavior of dislocations and the rate of dynamic recovery. ${ }^{9}$

Since the chemical compositions, volume fractions and morphologies of intermetallic phases exert significant effects on the mechanical properties of the 6xxxtype Al-alloys, ${ }^{10}$ it is also important to know where, when and what kind of intermetallic may form during a solidification process. Hence, the improvement of the metallurgical process and the use of heat-treatable aluminum alloys as structural materials are then strongly related to the understanding of the influence of the precipitation process and an intermetallic with its physical and mechanical properties on the behavior of the Al alloys. The 6000-series alloys generally have a lower formability than the 5000 -series $\mathrm{Al}-\mathrm{Mg}$ alloys. However, they can obtain a higher strength after the paint-baking process. ${ }^{11}$ This is the major advantage of the 6000-series alloys.

The objectives of the present study were as follows: a) to develop a suitable age-hardening heat-treatment

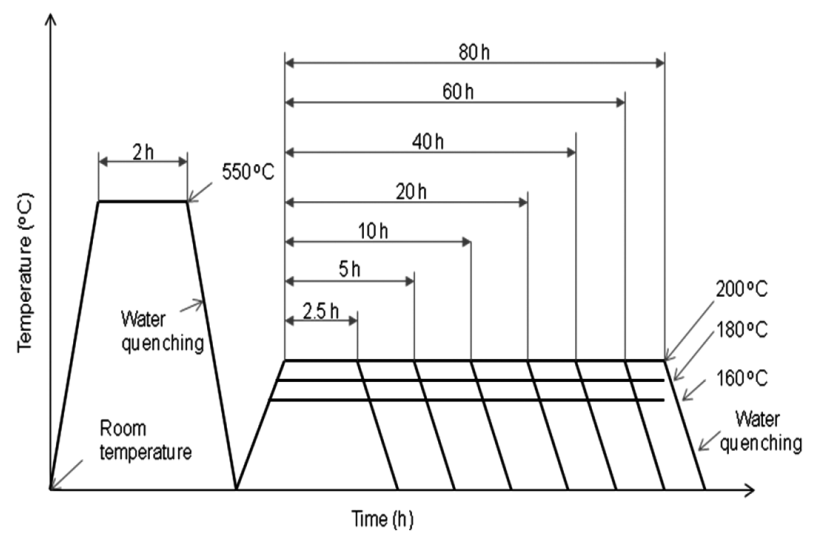

Figure 1: Schematic representations of the aging-treatment procedures

Slika 1: Shematski prikaz postopkov staranja process with specified parameters for AA6061, b) to investigate the effects of the artificial aging temperature and time on the mechanical properties and springback behavior of AA6061, c) to discuss the relationship between the springback behavior and the mechanical properties.

\section{MATERIALS AND EXPERIMENTAL PROCEDURE}

In this study, a commercially available AA6061-O with a thickness $1 \mathrm{~mm}$ produced by AMAG rolling was used in its as-received condition. The chemical composition of the alloy is given in Table $\mathbf{1}$.

Table 1: Chemical composition of AA6061 in mass fractions, $w / \%$ Tabela 1: Kemijska sestava AA6061 v masnih deležih, w/\%

\begin{tabular}{|c|c|c|c|c|c|c|c|}
\hline $\mathrm{Mg}$ & $\mathrm{Si}$ & $\mathrm{Cu}$ & $\mathrm{Mn}$ & $\mathrm{Fe}$ & $\mathrm{Cr}$ & $\mathrm{Zn}$ & $\mathrm{Al}$ \\
\hline 0.80 & 0.63 & 0.21 & 0.08 & 0.38 & 0.17 & 0.03 & balance \\
\hline
\end{tabular}

All the 6061 Al-alloy specimens, except those in the as-received condition, were solution heat treated at 550 ${ }^{\circ} \mathrm{C}$ for $2 \mathrm{~h}$ followed by quenching in water at room temperature $(R T)$. After the solution heat treatment, all the AA6061 specimens were kept in a refrigerator to avoid natural aging of the alloy at room temperature. Following the solution heat treatment, the specimens were artificially age hardened in a furnace at $(160,180$, and 200) ${ }^{\circ} \mathrm{C}$ for periods of $(2.5,5,10,20,40,60$, and 80) $\mathrm{h}$ and subsequently quenched in water. The aging-treatment procedure is illustrated in Figure 1.

Uniaxial tensile tests were performed at $R T$. The tensile-test samples were prepared by water-jet cutting according to the ASTM E8 standard along $0^{\circ}$ (rolling), $45^{\circ}$ (diagonal), and $90^{\circ}$ (transverse) directions. The deformation speed was chosen as $25 \mathrm{~mm} / \mathrm{min}$ and the gage length was $50 \mathrm{~mm}$. The tests were conducted with a Shimadzu Autograph $100 \mathrm{kN}$ tensile-testing machine and the deformation was measured with a video-type extensometer. Two lines were scribed on the gage length. Basically, the video-type extensometer followed these two lines during the test and calculates the strains.

For the springback measurements, a V-shaped die with a $60^{\circ}$ angle integrated with the tensile-testing machine was used. Rectangular test samples were prepared in the rolling direction. All the tests were done at $R T$ using a constant deformation speed of $25 \mathrm{~mm} / \mathrm{min}$. The hardness was measured using a Mitutoyo HV-112 Vickers-hardness tester with a $10 \mathrm{~kg}$ load. Three measurements were made for each sample under each experimental condition and the results were averaged.

\section{RESULTS AND DISCUSSION}

First, the mechanical properties of the as-received alloy at $R T$ and the $0.0083 \mathrm{~s}^{-1}$ strain rate were determined. The results were as follows: Young's Modulus $E$ 
$=68.9 \mathrm{GPa}$, the yield strength $(Y S)$ was $55.2 \mathrm{MPa}$, the ultimate tensile strength (UTS) was $124 \mathrm{MPa}$, hardening coefficient $K$ was $332 \mathrm{MPa}$, hardening exponent $n$ was 0.296 , normal anisotropy $r_{\mathrm{n}}$ was 0.68 , the total elongation (TE) was $25 \%$ and Vickers hardness was $53 \mathrm{HV}$.

\subsection{Effects of the artificial-aging temperature and time on the hardness of AA6061}

The hardness variations for the alloy with various aging temperatures and times are displayed in Figure 2. This figure indicates that the hardness of AA6061 depends strongly on both the aging time and the temperature. At each aging temperature, the hardness of the alloy first increases with the aging time and reaches its maximum value. After reaching its maximum value, the hardness of the alloy begins to decrease gradually with the aging time. The increase in the hardness can be explained with the diffusion-assisted mechanism and also with the hindrance of dislocation by impurity atoms, i.e., the foreign particles of the second phase since the material, after being quenched from $550{ }^{\circ} \mathrm{C}$ (solution heat treatment), has an excessive vacancy concentration. Beyond the peak hardness, the hardness value drops. The decrease in the hardness is associated with an increase in the inter-particle spacing among precipitates, which makes the dislocation bowing much easier. ${ }^{12,13}$ Moreover, the coarsening of the silicon phase results in a reduction of the hardness values.

The hardness of the alloy immediately after the solutionizing is $54 \mathrm{HV}$. The alloy achieves its maximum hardness at $160{ }^{\circ} \mathrm{C}$ when aged for $40 \mathrm{~h}$. At this aging temperature and time, the alloy produces a hardness structure that is attributed to the acceleration of $\mathrm{Mg}_{2} \mathrm{Si}$ and other strengthened phases. ${ }^{14}$ At this aging temperature and time, the microstructure of the alloy is refined by the heat treatment into a fine dispersion of $\mathrm{Mg}_{2} \mathrm{Si}$ and

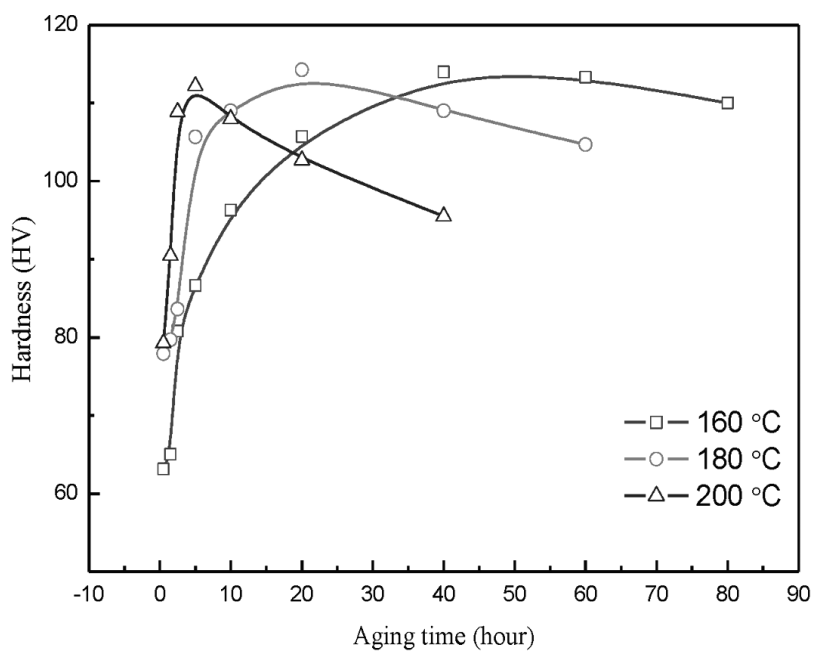

Figure 2: Effects of artificial-aging temperature and time on hardness of AA6061 alloy

Slika 2: Vpliv temperature in časa umetnega staranja na trdoto zlitine AA6061 other strengthening phases with $\beta$ " as the strengthening phase ${ }^{15}$ which is coherent, along with the semi-coherent clusters of $\beta\left(\mathrm{Mg}_{2} \mathrm{Si}\right)$. The solute atoms form clusters serving as a barrier to the movement of dislocation and, hence, a higher hardness is obtained.

At a higher aging temperature, the alloy is expected to develop hardness at a shorter aging time because the rate of precipitation of the second phase atoms is faster. With the particles of the second-phase precipitates, solute atoms and grain boundaries ${ }^{16,17}$ a higher hardness is expected to develop in the alloy.

\subsection{Effects of the artificial-aging temperature and time on the yield and tensile strengths of AA6061}

The variation in the yield and tensile strengths of the alloy, when exposed to different aging temperatures for different intervals of the time, is shown in Figures $\mathbf{3}$ and 4, respectively.

At each aging temperature, it can be observed that initially the yield and tensile strengths of the alloy increase with the aging time and reach their peak values. After reaching the peak values, continuous decreases in the yield and tensile strengths are observed with the aging time. The peak-strength values of the alloy for the aging temperatures of $(160,180$ and 190$){ }^{\circ} \mathrm{C}$ were obtained when the alloy was aged for $(60,10$ and 5$) \mathrm{h}$, respectively. The initial increases in the yield and tensile strengths are due to the vacancy-assisted diffusion mechanism and the formation of a high volume fraction of GP zones followed by the formation of metastable $\beta$ ", and $\beta$ ' precipitates, disturbing the regularity in the lattices. Siddiqui et al. ${ }^{18}$ showed that as the aging temperature and time increase, the density of GP zones also increases. Hence, the degree of irregularity in the lattices causes an increase in the mechanical properties of the Al-Mg-Si alloy. The strengthening effect of the AA6061

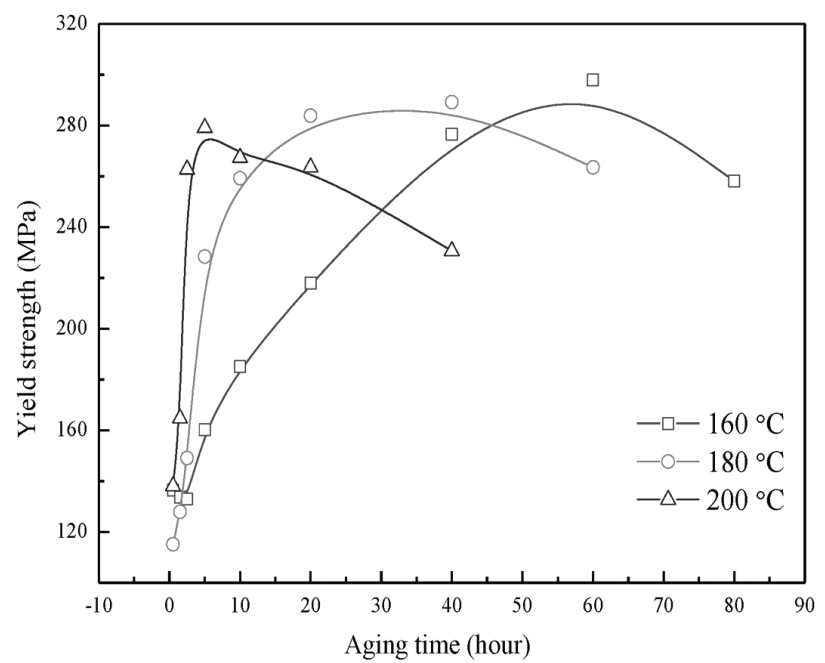

Figure 3: Effects of artificial-aging temperature and time on yield strength $(Y S)$ of AA6061 alloy

Slika 3: Vpliv temperature in časa umetnega staranja na mejo tečenja (YS) zlitine AA6061 


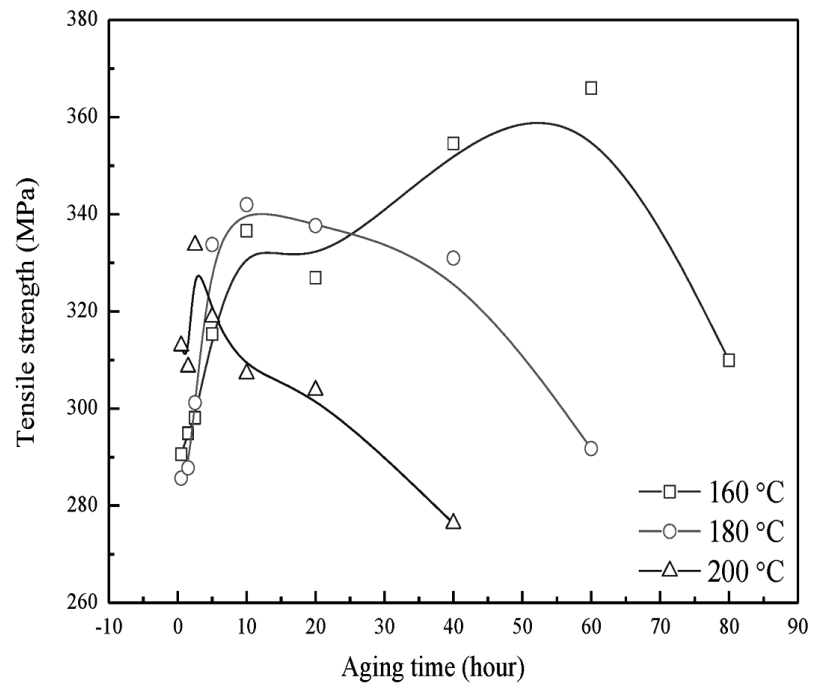

Figure 4: Effects of artificial-aging temperature and time on tensile strength $(T S)$ of AA6061 alloy

Slika 4: Vpliv temperature in časa umetnega staranja na natezno trdnost (TS) zlitine AA6061

alloy can also be interpreted as a result of an interference with the motion of dislocation due to the presence of foreign particles of any other phase.

In the aging process performed at high temperatures, the yield and tensile strengths reach their peak values in a very short period of time because the rate of precipitation of the second-phase atoms is faster, and precipitates form quickly. As the aging temperature decreases, this period is prolonged. In addition, at high temperatures, the drops in the yield and tensile strengths after the peak values are very fast and occur in a very short time, while at low temperatures they are slower and occur after a long time.

The difference between the tensile strength after a shorter aging time, for example, $5 \mathrm{~h}$ and that obtained

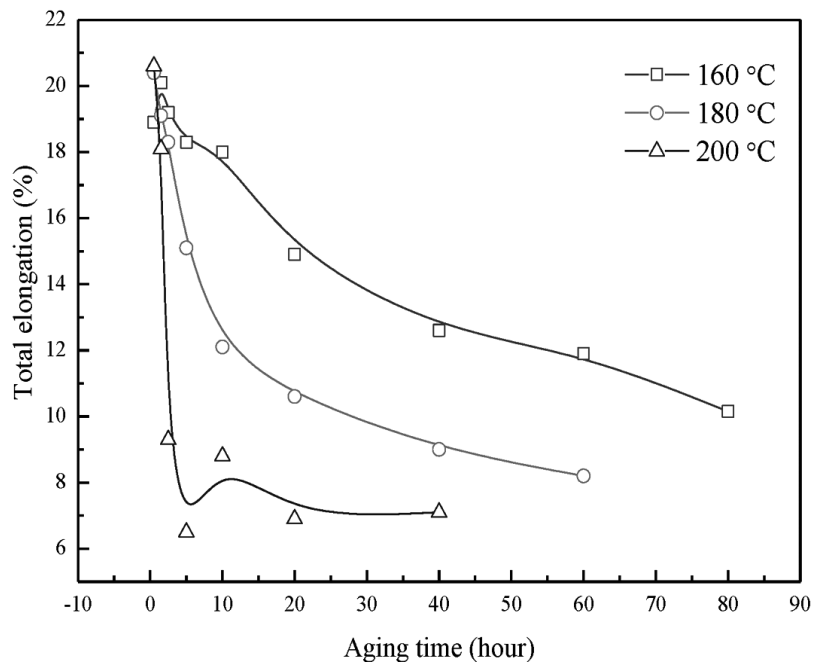

Figure 5: Effects of artificial-aging temperature and time on the total elongation (TE) of AA6061 alloy

Slika 5: Vpliv temperature in časa umetnega staranja na celotni raztezek (TE) zlitine AA6061 over a longer time of $10 \mathrm{~h}$ at $180{ }^{\circ} \mathrm{C}$ may be due to the incoherent precipitates that appeared in the early hours and disappeared later due to the diffusion of the precipitates and the homogenization of the matrix. However, since the diffusion/precipitation processes are slower at lower temperatures than at higher temperatures, the precipitates appeared in the aluminum matrix only after the aging for longer periods. ${ }^{19,20}$

The alloy achieves its maximum yield-strength values at the aging temperatures of $(160,180 \text { and } 190)^{\circ} \mathrm{C}$ when aged for $(60,40$ and 5$) \mathrm{h}$, respectively, thereafter, a decrease occurs as the aging time progresses. For example, at $180{ }^{\circ} \mathrm{C}$, the yield strength decreases significantly from its maximum value of $290 \mathrm{MPa}$ to a value of less than $260 \mathrm{MPa}$ after another $20 \mathrm{~h}$ of aging. This could be due to coalescence of the precipitates into larger particles and a bigger grain size, causing fewer obstacles to the movement of dislocation, and also due to the annealing out of the defects.

The variation in the ductility of AA6061 with the artificial aging temperature and time is shown in Figure 5. The ductility follows an inverse relation with the strength, as expected. The elongation of AA6061 decreases gradually with both the increasing aging temperature and the time. The over-aged specimen has a ductility as low as $7 \%$ when precipitation hardened at $200{ }^{\circ} \mathrm{C}$ for $40 \mathrm{~h}$. Since the elongations of the aged specimens in all the conditions are larger than that of the as-received specimen (a $25 \%$ elongation) it can be said that the aging has a negative effect on the ductility of the alloy. But low-temperature aging has a positive effect in terms of the total elongation as seen in Figure 5.

\subsection{Effects of the artificial-aging temperature and time on the springback behavior of AA6061}

In the sheet-metal forming process, springback has always been a series problem. Basically, the elastic recovery occurs after removing the tools. Springback produces a decrease in the quality of the formed parts (a poor dimensional accuracy of the formed parts), therefore, representing a major defect in the sheet-metal forming processes. The factors such as material properties (elastic modulus, yield stress, hardening exponent, slope of the true stress/strain curve, or tangent modulus, $\mathrm{d} \sigma / \mathrm{d} \varepsilon$, and normal anisotropy), process variables (load, thickness of the sheet metal, die angle, punch radius and die gap) and lubrication affect the springback behavior. The springback of aluminum alloys has been a subject of major interest in sheet-metal forming. Numerous studies focus on springback from experimental, analytical or numerical viewpoints. A complete review on springback studies is presented by Wagoner. ${ }^{21}$ Although much progress has been done, there are still needs for further research to solve this problem. The material properties affecting the springback must be strictly determined to prevent undesired shapes. Trial and error methods are still being 


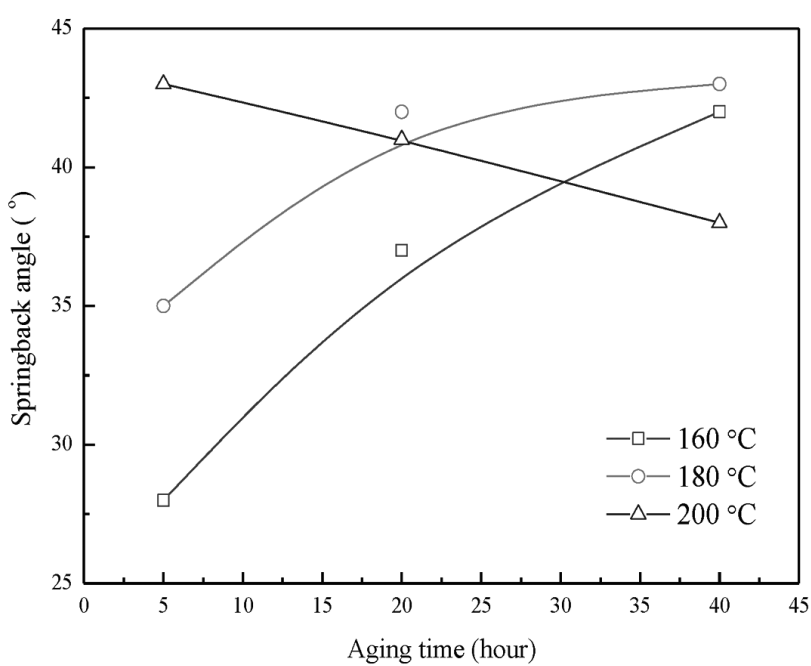

Figure 6: Effects of artificial-aging temperature and time on springback behavior of AA6061 alloy

Slika 6: Vpliv temperature in časa umetnega staranja na vzmetnost zlitine AA6061

used to establish suitable procedures for solving these elastic-distortion problems.

In this research, a springback evaluation of the AA6061 specimens artificially age hardened at $(160,180$ and 200) ${ }^{\circ} \mathrm{C}$ for periods of $(5,20,4) \mathrm{h}$ was carried out in a $\mathrm{V}$-shaped die with an angle of $60^{\circ}$ at $R T$ and a strain rate of $0.0083 \mathrm{~s}^{-1}$. Figure 6 shows the effects of the artificial-aging temperature and time on the springbackangle variation of AA6061. The springback angle of the alloy increases with the increasing artificial-aging temperature and time; however, it decreases with the increasing aging time at $200{ }^{\circ} \mathrm{C}$.

The specimen in the as-received condition exhibited a smaller springback angle $\left(7^{\circ}\right)$ than the aged specimens in all the conditions. It is considered that this

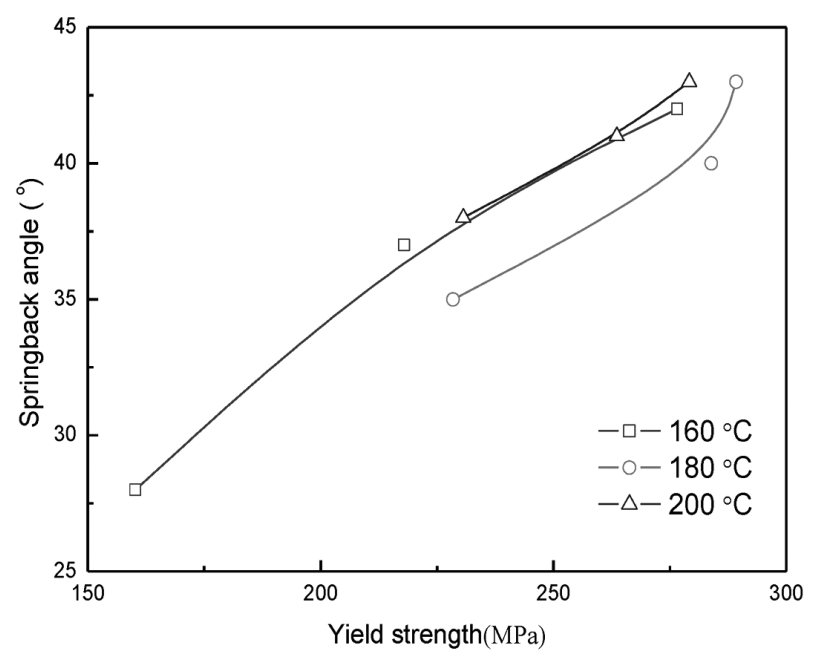

Figure 7: Variation of springback angle versus yield strength at various aging temperatures

Slika 7: Spreminjanje kota vzmetnosti od natezne trdnosti pri različnih temperaturah staranja phenomenon is related to the changes in the properties of the material. The material properties that control the amount of the springback that occurs after the forming operation are the elastic modulus, the yield strength, the slope of the true stress/strain curve, or the tangent modulus, the normal anisotropy, and the strain-hardening exponent.

Figure 7 shows the variations in the yield strength versus springback at various aging temperatures. From the figure it is evident that the yield strength of the alloy increases with the increasing aging time at $160{ }^{\circ} \mathrm{C}$ and $180{ }^{\circ} \mathrm{C}$; however, it decreases with the increasing aging time at $200{ }^{\circ} \mathrm{C}$. It can be concluded that the springback increases as the yield strength of the material increases.

With the increasing yield strength, the value of the flow stress and the stored elastic energy, being at the same strain level, increase. Since the stored elastic energy is high for a metal sheet with a higher yield strength, the changes in the strain produced by the elastic recovery are larger when the externally applied bending forces are released. The elastic recovery, i.e., the springback, being at the same strain level, is larger for a sheet metal with a larger yield strength.
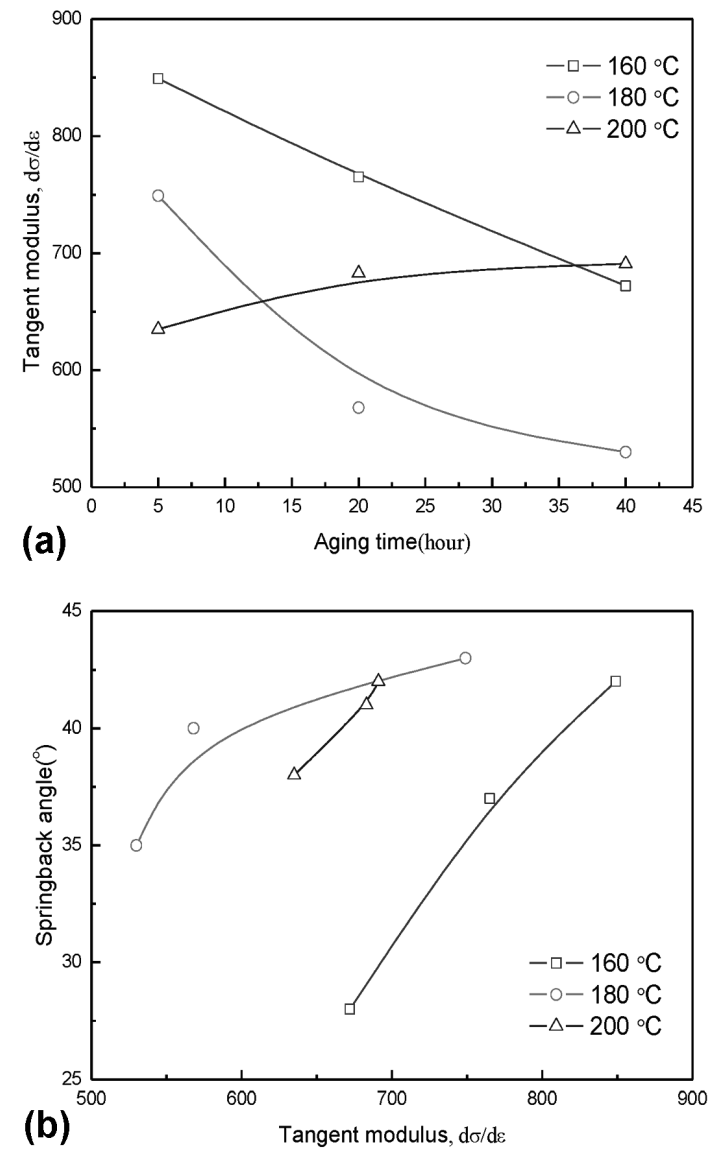

Figure 8: Variation of: a) tangent modulus versus aging time, b) springback angle versus tangent modulus at various aging temperatures

Slika 8: Spreminjanje: a) tangentnega modula od časa staranja, b) kota vzmetnosti od tangentnega modula pri različnih temperaturah staranja 


\section{A. POLAT et al.: EFFECTS OF THE ARTIFICIAL-AGING TEMPERATURE AND TIME ...}

The effect of the tangent modulus on the amount of springback is shown in Figures $\mathbf{8 a}$ and $\mathbf{8 b}$. It is seen that a higher tangent modulus causes a larger springback for all the aging temperatures. Since the tangent modulus of the aged specimens is larger than that of the specimen in the as-received condition for the same plastic strain, an extra reverse-bending force is introduced after the bending of the aged specimens, which is expected to increase the springback angle. Ozturk et al. ${ }^{22}$ observed a similar behavior where the strain-hardening rate decreases substantially with the increasing aging time. They also found that the anisotropy in the rolling direction decreased, while in the transverse direction it increased with the aging time.

Material scientists are focused on increasing the normal anisotropy using a favorable texture with a better formability, and therefore, it is necessary to understand the effect of normal anisotropy on the springback. The effect of normal anisotropy on the springback was studied by $\mathrm{Liu}^{23}$ and Verma ${ }^{24}$. They showed that the springback increases when the normal anisotropy increases. In

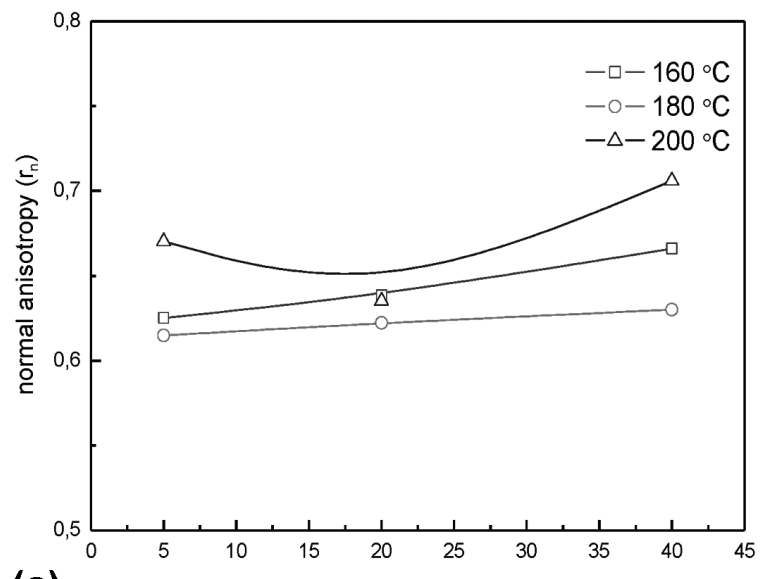

(a)

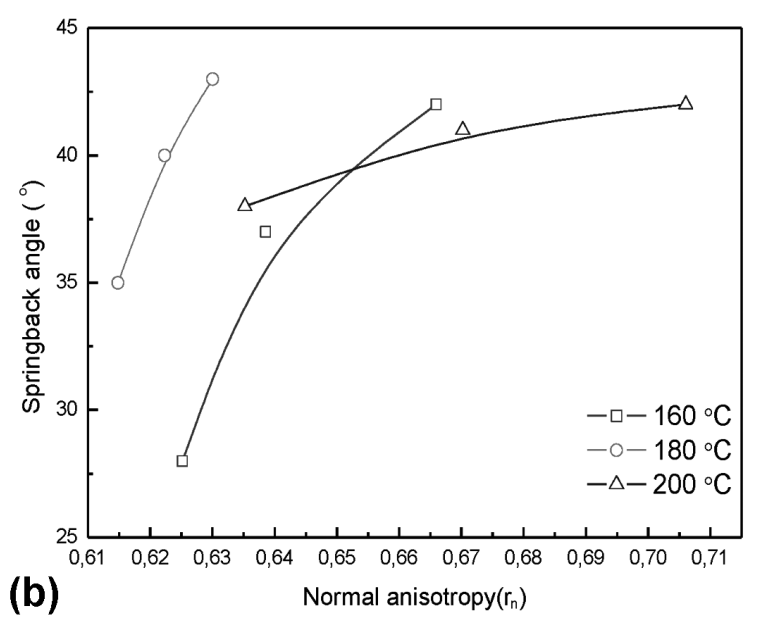

Figure 9: Variation of: a) normal anisotropy versus aging time, b) normal anisotropy versus springback angle at various aging temperatures Slika 9: Spreminjanje: a) normalne anizotropije od časa staranja, b) normalne anizotropije od kota vzmetnosti pri različnih temperaturah staranja the present work, the effect of the aging parameter on the amount of normal anisotropy and the springback angle is shown in Figures $9 \mathbf{a}$ and $\mathbf{9 b}$.

The specimen in the as-received condition exhibited a larger normal anisotropy $\left(r_{\mathrm{n}}=0.68\right)$ than the aged specimens in all the conditions. According to the studies of $\mathrm{Liu}^{23}$ and $\mathrm{Verma}^{24}$, this indicates that aging has a positive effect on the springback angle of the alloy because the normal anisotropy is decreased by the aging parameters. The strain hardening is an ability of a material to strengthen or harden with the increasing strain level and it is one of the most important properties influencing the formability of sheet metals. In the materials with a high value, the flow stress increases rapidly with strain. A high value is also an indication of a good formability in a stretching operation. In the region of a uniform elongation, the strain-hardening coefficient is defined as $n=\operatorname{dln} \sigma / \mathrm{d} \ln \varepsilon$ where $\sigma$ is the true stress and $\varepsilon$ is the true strain.
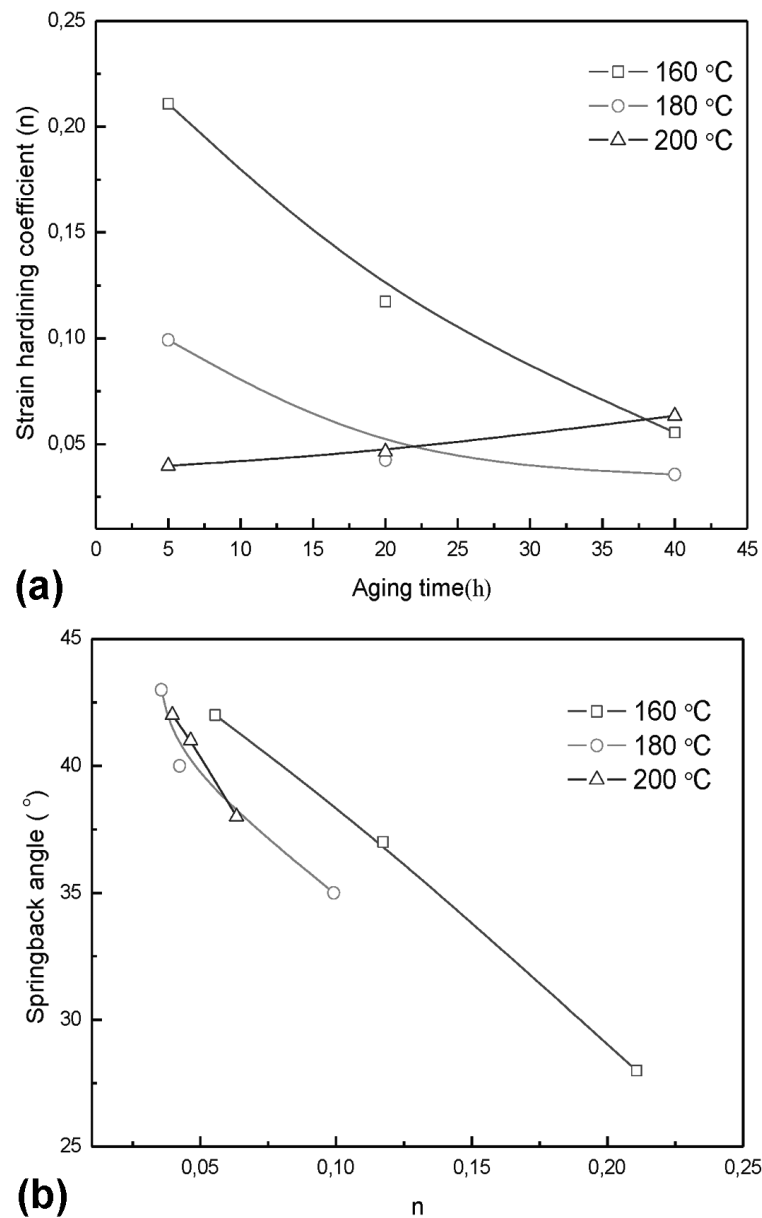

Figure 10: Variation of: a) hardening coefficient $(n)$ versus aging time, b) springback angle versus strain-hardening coefficient at various aging temperatures

Slika 10: Spreminjanje: a) koeficienta utrjevanja ( $n$ ) od časa staranja, b) kota vzmetnosti od koeficienta napetostnega utrjevanja pri različnih temperaturah staranja 
Figure 10 shows the relationships between the springback angle and the strain-hardening exponent of the aluminum alloy at different aging temperatures.

The springback angle is found to decrease with the increasing strain-hardening exponent for all of the aging temperatures. It is well-known that the larger the hardening exponent, the lower is the stress needed to achieve the same deformation during the $\mathrm{V}$ bending of sheet metal. Thus, according to the elastic unloading springback principle, the springback is larger for a sheet with a low $n$ or vice-versa.

Since the hardening exponent of the aged specimens in all the conditions is larger than that of the as-received specimen, it seems that aging has a negative effect on the springback angle of the alloy.

\section{CONCLUSIONS}

In this study, the effects of the artificial-aging temperature and time on the mechanical properties and springback properties of AA6061 are studied. The following conclusions are made.

The peak-strength values of the alloy for the aging temperatures of $(160,180$ and 190$){ }^{\circ} \mathrm{C}$ were obtained when the alloy was aged for $(60,10$ and 5$) \mathrm{h}$, respectively.

The aging between $5 \mathrm{~h}$ and $40 \mathrm{~h}$ at $180{ }^{\circ} \mathrm{C}$ is the most suitable combination of time and temperature exhibiting the maximum hardness, yield strength and tensile strength of the alloy.

A decrease in the mechanical properties of the alloy in the over-aging conditions (an increase in the artificial-aging temperature and time) occurred because of the coalescence of the precipitates into larger particles, a bigger grain size, and also due to the annealing of the defects.

The specimen in the as-received condition exhibited a smaller springback angle than the aged specimens in all the conditions.

\section{REFERENCES}

${ }^{1}$ S. J. Murtha, SAE International Journal of Materials and Manufacturing, 104 (1995), 657-666, doi:10.4271/950718

${ }^{2}$ F. Ozturk, A. Sisman, S. Toros, S. Kilic, R. C. Picu, Materials and Design, 31 (2010), 972-975, doi:10.1016/j.matdes.2009.08.017

${ }^{3}$ J. Buha, R. N. Lumley, A. G. Crosky, Metallurgical Materials Transactions, 37A (2006), 3119-3130, doi:10.1007/s11661-006-0192-x
${ }^{4}$ G. A. Edwards, K. Stiller, G. L. Dunlop, M. J. Couper, Acta Materialia, 46 (1998), 3893-3904, doi:10.1016/S1359-6454(98)00059-7

${ }^{5}$ J. Buha, R. N. Lumley, A. G. Crosky, K. Hono, Acta Materialia, 55 (2007), 3015-3024, doi:10.1016/j.actamat.2007.01.006

${ }^{6}$ C. D. Marioara, H. Nordmark, S. J. Andersen, R. Holmestad, Journal of Materials Science, 41 (2006), 471-78, doi:10.1007/s10853-0052470-1

${ }^{7}$ S. Pogetsher, H. Antrekowitsch, H. Leitner, T. Ebner, P. J. Uggowitzer, Acta Materialia, 59 (2011), 3352-3363, doi:10.1016/ j.actamat.2011.02.010

${ }^{8}$ S. J. Anderson, H. W. Zandbergen, J. E. Jansen, C. Taeholt, U. Tundal, O. Reiso, Acta Materialia, 46 (1998), 3283-3298, doi:10.1016/ S1359-6454(97)00493-X

${ }^{9}$ S. K. Panigrahi, R. Jayaganthan, Materials Science and Engineering A, 528 (2011), 3147-3160, doi:10.1016/j.msea.2011.01.010

${ }^{10}$ G. Mrówka-Nowotnik, J. Sieniawski, Journal of Materials Processing Technology, 162-163 (2005), 367-372, doi:10.1016/j.jmatprotec. 2005.02.115

${ }^{11}$ G. B. Burger, A. K. Gupta, P. W. Jeffrey, D. J. Llyod, Materials Characterization, 35 (1995), 23-39, doi:10.1016/1044-5803(95)00065-8

${ }^{12}$ O. El Sebaie, A. M. Samuel, F. H. Samuel, H. W. Doty, Materials Science and Engineering A, 480 (2008), 342-355, doi:10.1016/ j.msea.2007.07.039

${ }^{13}$ D. D. Risanti, M. Yin, P. E. J. Rivera Diazdel Castillo, S. Vau der Zwang, Materials Science and Engineering A, 523 (2009), 99-111, doi:10.1016/j.msea.2009.06.044

${ }^{14}$ M. Tiryakioglu, J. Campbell, J. T. Staley, Materials Science and Engineering A, 361 (2003), 240-248, doi:10.1016/S0921-5093(03) 00514-8

${ }^{15}$ A. K. Gupta, D. J. Lloyd, S. A. Court, Materials Science and Engineering A, 316 (2001), 11-17, doi:10.1016/S0921-5093(01)01247-3

${ }^{16}$ A. M. Kliauga, E. A. Vieira, M. Ferrante, Materials Science and Engineering A, 480 (2008), 5-16, doi:10.1016/j.msea.2007.07.091

${ }^{17}$ G. E. Dieter, Mechanical metallurgy, 2nd ed., McGraw-Hill International Book Company, 1981

${ }^{18}$ R. A. Siddiqui, H. A. Abdullah, K. R. Al-Belushi, Journal of Materials Processing Technology, 102 (2000), 234-240, doi:10.1016/ S0924-0136(99)00476-8

${ }^{19}$ D. A. Porter, K. E. Easterling, Phase Transformations in Metals and Alloys, Van Nostrand Reinhold Co. Ltd., New York, NY 1981, 162-168

${ }^{20}$ W. D. J. Callister, Materials Science and Engineering, John Wiley and Sons Inc., 1997

${ }^{21}$ R. H. Wagoner, Fundamental aspects of spring-back in sheet metal forming, Proceedings of NUMISHEET, Jeju Island, Korea, 2002, $13-24$

${ }^{22}$ F. Ozturk, E. Esener, S. Toros, R. C. Picu, Materials and Design, 31 (2010) 10, 4847-4852, doi:10.1016/j.matdes.2010.05.050

${ }^{23}$ D. K. Liu, Journal of Materials Processing Technology, 66 (1997), 9-17, doi:10.1016/S0924-0136(96)02453-3

${ }^{24}$ R. K. Verma, A. Haldar, Journal of Materials Processing Technology, 190 (2007), 300-304, doi:10.1016/j.jmatprotec.2007.02.033 